\title{
Fluid shear stress induces osteoblast differentiation and arrests the cell cycle at the G0 phase via the ERK1/2 pathway
}

\author{
LIYIN YU ${ }^{1}$, XINGFENG MA ${ }^{1}$, JUNQIN SUN ${ }^{1}$, JIE TONG $^{1}$, LIANG SHI ${ }^{1}$, LIJUN SUN $^{2}$ and JIANBAO ZHANG ${ }^{1}$ \\ ${ }^{1}$ Key Laboratory of Biomedical Information Engineering of Ministry of Education, School of \\ Life Science and Technology, Xi'an Jiaotong University, Xi'an, Shaanxi 710049; ${ }^{2}$ Institute of \\ Sports Biology, Shaanxi Normal University, Xi'an, Shaanxi 710119, P.R. China
}

Received February 18, 2017; Accepted August 10, 2017

DOI: $10.3892 / \mathrm{mmr} .2017 .7720$

\begin{abstract}
Numerous studies have demonstrated that fluid shear stress (FSS) may promote the proliferation and differentiation of osteoblast cells. However, proliferation and differentiation are mutually exclusive processes and are unlikely to be promoted by FSS simultaneously. Cell proliferation and differentiation induced by FSS has rarely been reported. In order to provide an insight into this process, the present study investigated the effects of FSS on osteoblast-like MC3T3 cells in the G0/G1 phase, the period during which the fate of a cell is determined. The results of the present study demonstrated that FSS promoted alkaline phosphatase (ALP) activity, and the mRNA expression and protein expression of osteocalcin, collagen type I and runt-related transcription factor 2 (Runx2), while inhibiting DNA synthesis and arresting the cell cycle at the G0/G1 phase. The increase in Runx 2 and ALP activity was accompanied by the activation of calcium/calmodulin-dependent protein kinase type II (CaMK II) and extracellular signal-regulated kinases $1 / 2$ (ERK1/2), which was completely abolished by treatment with KN93 and U0126, respectively. In addition, the inhibition of
\end{abstract}

Correspondence to: Professor Jianbao Zhang, Key Laboratory of Biomedical Information Engineering of Ministry of Education, School of Life Science and Technology, Xi'an Jiaotong University, 541 Xian Ning West Road, Xi'an, Shaanxi 710049, P.R. China

E-mail: zhangjb@mail.xjtu.edu.cn

\begin{abstract}
Abbreviations: FSS, fluid shear stress; ERK, extracellular signal-regulated kinase; ALP, alkaline phosphatase; $\mathrm{pRb}$, phosphorylated retinoblastoma-associated protein; CaMK II, calcium/calmodulin-dependent protein kinase type II; Runx2, runt-related transcription factor 2; COLL I, collagen type I; OCN, osteocalcin; CDK, cyclin-dependent kinase; FBS, fetal bovine serum; BrdU, bromodeoxyuridine; MEM, minimum essential medium
\end{abstract}

Key words: fluid shear stress, osteoblast, cell differentiation, cell cycle
ERK1/2, although not CaMK II, decreased p21 Cip/Kip activity, resulting in an increase in cell number and $\mathrm{S}$ phase re-entry. The results of the present study indicated that in the G0/G1 phase, FSS promoted osteoblast differentiation via the CaMK II and ERK1/2 signaling pathways, and blocked the cell cycle at the G0/G1 phase via the ERK1/2 pathway only. The present findings provided an increased understanding of osteoblastic mechanobiology.

\section{Introduction}

Fluid shear stress (FSS), which is generated by fluid flow inside the lacunar-canalicular networks and trabecular spaces within bone tissue, is important for the maintenance of skeletal architectural integrity $(1,2)$. Previous studies have demonstrated that FSS may promote the proliferation and differentiation of osteoblasts (3-5). The cells used in the literature are at various stages of the cell cycle rather than in a single phase, thus the effect of FSS on osteoblasts in the G0/G1 phase remains unclear. Proliferation and differentiation are exclusive physiological processes in cells and may not be simultaneously induced by FSS in a single cell. It is therefore necessary to elucidate precisely how the proliferation and differentiation of osteoblasts are regulated by FSS.

The associated events in the G0/G1 phase for a cell determine its fate with regards to proliferation or differentiation. Restriction point passage, which promotes cell cycle progression and $\mathrm{S}$ phase entry, is essential to drive cell proliferation, whereas cells which do not pass the restriction point may return to the G0/G1 phase in quiescence or may differentiate (6). The product of the retinoblastoma-associated protein gene $(\mathrm{Rb})$ has been reported to be an important regulatory factor in restriction point passage (7). The phosphorylation of $\mathrm{Rb}$, induced by cyclin-dependent kinases 4/6 (CDK4/6) and further activated by $\mathrm{CDK} 2$, promotes cell passage through the restriction point and $\mathrm{S}$ phase entry (8). Dephosphorylated $\mathrm{Rb}$ acts as a transcriptional coactivator required for runt-related transcription factor 2 (Runx2) activity and osteogenic differentiation $(9,10)$. These previous results indicated that the extent of phosphorylation of phosphorylated $(\mathrm{p}) \mathrm{Rb}$ may determine the initiation of proliferation or differentiation in cells. Therefore, the present study sought to investigate how G0/G1 phase osteoblasts responded to FSS and whether pRb was involved. 
The release of intracellular $\mathrm{Ca}^{2+}$, activation of extracellular signal regulated kinases 1/2 (ERK1/2), and Rho signaling have been implicated in the process of osteoblast proliferation and differentiation induced by FSS (11-18). $\mathrm{Ca}^{2+}$ is a universal intracellular secondary messenger. The blockade of $\mathrm{Ca}^{2+}$ signaling was demonstrated to completely inhibit FSS-induced osteoblast proliferation and differentiation (4). It has been demonstrated that the ubiquitously-expressed calcium/calmodulin-dependent protein kinase type II (CaMK II), triggered by $\mathrm{Ca}^{2+}$ signaling, is involved in the regulation of cell proliferation and differentiation (19-20). ERK1/2 is an important component in the osteogenic action of FSS $(3,4,18)$. There is evidence that crosstalk exists between various signaling pathways, and that the activation of $\mathrm{Ca}^{2+}$ signaling and ERK1/2 are important downstream events of a number of these pathways (3,14-15,17,21-25). Therefore, the present study investigated how FSS affected the proliferation and differentiation of osteoblasts in the G0/G1 phase, with emphasis on CaMK II and ERK1/2.

\section{Materials and methods}

Reagents. The reagents used in the present study were obtained from the following sources: MC3T3-E1 subclone 14 were from the American Type Culture Collection (Manassas, VA, USA; cat. no. CRL-2594); $\alpha$-minimum essential medium (MEM) was from Hyclone (GE Healthcare Life Sciences, Logan, UT, USA; cat. no. SH30265.01B); fetal bovine serum (FBS) was from Gibco (Thermo Fisher Scientific, Inc., Waltham, MA, USA; cat. no. 10082147); mouse anti-Runx2 (cat. no. ab76956), anti-collagen type I antibody (COLL I; cat. no. ab34710) and anti-osteocalcin antibody (OCN: cat. no. ab93876) were from Abcam (Cambridge, UK); rabbit anti-p21 ${ }^{\text {Cip/Kip }}$ antibody was from Abcam (cat. no. ab109199); pRb (Ser780) rabbit monoclonal antibody was from Cell Signaling Technology, Inc. (Danvers, MA, USA; cat. no. D59B7); rabbit anti-p-ERK1/2 antibody was from Cell Signaling Technology, Inc. (cat. no. 14474); rabbit anti-CaMKII- $\alpha$ antibody (cat. no. ab50202), rabbit anti-CaMKII- $\gamma$ antibody (cat. no. ab37999) and mouse anti- $\beta$-actin antibody (cat. no. ab6276) were all from Abcam. KN93 was obtained from Calbiochem (Merck $\mathrm{KGaA}$, Darmstadt, Germany) and was dissolved in dimethyl sulfoxide. U0126 was obtained from Sigma-Aldrich (Merck $\mathrm{KGaA}$ ). The alkaline phosphatase (ALP) activity kit (cat. no. A059-2) and ALP staining kit (cat. no. D001) were from Nanjing Jiancheng Bioengineering Institute (Nanjing, China). Bromodeoxyuridine (BrdU; cat. no. 11467229001) was from Roche Diagnostics GmbH (Mannheim, Germany). Trypsin and EDTA were from Irvine Scientific (Santa Ana, CA, USA).

Cell culture and G0/G1 phase arrest. The osteoblastic cell line MC3T3-E1 was cultured in $\alpha$-MEM with $10 \% \mathrm{FBS}, 100 \mathrm{U} / \mathrm{ml}$ penicillin and $100 \mathrm{~g} / \mathrm{ml}$ streptomycin. Cells were maintained in a humidified incubator at $37^{\circ} \mathrm{C}$ with $5 \% \mathrm{CO}_{2}$ and were subcultured every $48 \mathrm{~h}$. For the FSS experiments, 50,000 cells were seeded onto glass slides. Cell cycle arrest at the G0/G1 phase was achieved by serum deprivation. Cells were washed three times with PBS and cultured in serum-free $\alpha$-MEM for $24 \mathrm{~h}$. Fluid shear experiments were performed 3 days subsequently, when cells were $75-80 \%$ confluent and G0/G1-arrested. The flow medium consisted of $\alpha$-MEM containing 2\% FBS, $100 \mathrm{U} / \mathrm{ml}$ penicillin and $100 \mathrm{~g} / \mathrm{ml}$ streptomycin.

FSS experiment. Fluid flow was applied to cells in a parallel plate flow chamber using a closed flow loop. The system used a constant hydrostatic pressure head to drive media through the channel of the flow chamber, to subject the cell monolayer to steady laminar flow resulting in a well-defined FSS of 12 dyne $/ \mathrm{cm}^{2}$. The apparatus was maintained at $37^{\circ} \mathrm{C}$ throughout the duration of experimentation. The correlation between FSS and flow rate was calculated using the equation:

$$
\tau=\frac{6 \mu \mathrm{Q}}{\mathrm{bh}^{2}}
$$

where $\mathrm{Q}$ is the flow rate $\left(\mathrm{cm}^{3} / \mathrm{s}\right), \mu$ is the viscosity of the flow media $\left(0.01\right.$ dynes $\left./ \mathrm{cm}^{2}\right), \mathrm{h}$ is the height of the channel $(0.022 \mathrm{~cm}), \mathrm{b}$ is the slit width $(3.2 \mathrm{~cm})$, and $\tau$ is the wall shear stress $\left(\right.$ dyne $\left./ \mathrm{cm}^{2}\right)$. A programmable Harvard Syringe Pump (PHD programmable; Harvard Apparatus, Holliston, MA, USA) was used to perfuse the flow chamber with fresh media at the aforementioned shear rate of $12 \mathrm{dyne} / \mathrm{cm}^{2}$.

BrdU assay. The BrdU ELISA (Amersham Cell Proliferation Biotrak ELISA system, version 2; cat. no. 11647229001; GE Healthcare Life Sciences, Little Chalfont, UK) is based on the incorporation of BrdU during DNA synthesis in proliferating cells. Prior to labeling, cells were seeded at a density of 50,000/ml in 96-well plates. In order to quantify the cell proliferation, $10 \mu \mathrm{M}$ BrdU labeling reagent was added to each well $(100 \mu \mathrm{l} /$ well $)$ and the cells were incubated for $2-12 \mathrm{~h}$ in a humidified incubator at $37^{\circ} \mathrm{C}$ with $95 \%$ air and $5 \% \mathrm{CO}_{2}$. (Following stimulation, the DNA of MC3T3 cells will be duplicated during the first $12 \mathrm{~h}$. Thus, the times points of 2-12 $\mathrm{h}$ were selected to identify the cell proliferation rate.) The BrdU labeling reagent was removed from the wells and $200 \mu \mathrm{l}$ FixDenat solution (for cell fixation and DNA denaturation) was added, and the cells were incubated for $30 \mathrm{~min}$ at $15-25^{\circ} \mathrm{C}$. The FixDenat solution was removed, $100 \mu \mathrm{l} /$ well anti-BrdU-POD working solution was added and the cells were incubated for $90 \mathrm{~min}$ at $15-25^{\circ} \mathrm{C}$. The antibody conjugate was removed and the wells were rinsed three times with 200-300 $\mu 1 /$ well washing solution. The washing solution was subsequently removed and $100 \mu \mathrm{l} /$ well substrate solution was added, followed by incubation at $15-25^{\circ} \mathrm{C}$ until color development was sufficient for photometric detection (5-30 min). The reaction was stopped by adding $25 \mu \mathrm{l} 2 \mathrm{M} \mathrm{H}_{2} \mathrm{SO}_{4}$ solution to each well. The optical density (absorbance) of $150 \mu \mathrm{l}$ of the resultant yellow-colored solution was read at $450 \mathrm{~nm}$ in a 96-well microplate spectrophotometer. The absorbance values correlated directly with the amount of DNA synthesis and thereby to the number of proliferating cells in culture.

ALP activity and staining. Cells were washed with PBS and frozen $\left(-70^{\circ} \mathrm{C}\right)$ in $300 \mathrm{ml}$ Tris-Triton $(0.1 \mathrm{M}$ Tris-base; $0.2 \%$ TritonX-100). Following thawing, the cells were centrifuged $\left(13,800 \mathrm{x} \mathrm{g}\right.$ for $5 \mathrm{~min}$ at $\left.4^{\circ} \mathrm{C}\right)$ and the supernatant was used for analysis. ALP substrate was added to supernatant at a ratio of $1: 1$, and then the mixture was incubated at $37^{\circ} \mathrm{C}$ for $40 \mathrm{~min}$. Then $5 \mathrm{~g} / \mathrm{l} \mathrm{NaOH}$ was added to stop the reaction and the OD value 
Table I. Primers used for the reverse transcription-quantitative polymerase chain reaction.

\begin{tabular}{lll}
\hline Gene & \multicolumn{1}{c}{ Forward primer } & \multicolumn{1}{c}{ Reverse primer } \\
\hline COLL I & 5'-CGAGTCACACCGGAACTTGG-3' & 5'-GCAGGCAGGGCCAATGTCTA-3' \\
OCN & 5'-CTCTGTCTCTCTGACCTCACAG-3' & 5'-CAGGTCCTAAATAGTGATACCG-3' \\
Runx2 & 5'-GACTGTGGTTACCGTCATGGC-3' & 5'-ACTTGGTTTTTCATAACAGCGGA-3' \\
$\beta$-actin & 5'-CGTGGACATCCGCAAAGAC-3' & 5'-GCATTTGCGGTGGACGAT-3' \\
\hline
\end{tabular}

COLL I, collagen type I; OCN, osteocalcin; Runx2, runt-related transcription factor 2.

detected at a wavelength of $410 \mathrm{~nm}$. ALP activity was normalized to the total protein content. ALP staining was performed using the ALP staining kit, according to the manufacturer's protocol. The staining of ALP was observed by an inverted microscope (Leica Microsystems GmbH, Wetzlar, Germany).

Flow cytometry. MC3T3 cells were pelleted and fixed with $70 \%$ ethanol at $4^{\circ} \mathrm{C}$ for $2 \mathrm{~min}$. After the cells were digested with RNase, the DNA was stained with propidium iodide at $4^{\circ} \mathrm{C}$ for 30 mins in the dark, and then analyzed with a flow cytometer (FACSCalibur, BD). CytExpert version 1.2.11.0 (Beckman Coulter, Inc., Brea, CA, USA) was used for date analysis.

Reverse transcription-quantitative polymerase chain reaction (RT-qPCR) analysis. Total RNA was isolated from cells using the RNA Easy kit (Takara Biotechnology Co., Ltd., Dalian, China). RT was performed using a Prime Script ${ }^{\mathrm{TM}} \mathrm{RT}$ reagent kit (Takara Biotechnology Co., Ltd.). qPCR assays were performed using SYBR Premix Ex Taq ${ }^{\mathrm{TM}}$ (Takara Biotechnology Co., Ltd.) and the ABI Prism 7900 sequence detection system (Shanghai Ying Huai Jie Trading Co. Ltd., Shanghai, China) for quantitation. The RT reactions were performed with the following cycling conditions: $95^{\circ} \mathrm{C}$ for $30 \mathrm{sec}$, followed by 40 cycles of $95^{\circ} \mathrm{C}$ for $5 \mathrm{sec}$ and $56^{\circ} \mathrm{C}$ for $30 \mathrm{sec}$. The gene expression was normalized to $\beta$-actin gene expression. The $2^{-\Delta \Delta \mathrm{Cq}}$ method was used for normalization (26). Each sample was analyzed in triplicate, in a total volume of $20 \mu \mathrm{l}$ amplification mixture containing $10 \mu \mathrm{l} \mathrm{SYBR}$ Premix Ex Taq ${ }^{\mathrm{TM}}$ Mix (2X), $2 \mu \mathrm{l}$ cDNA, 0.8 of each primer, $0.4 \mu \mathrm{l}$ Rox I and $6 \mu \mathrm{l}$ of $\mathrm{H}_{2} \mathrm{O}$. Thermal cycling was performed by denaturation at $95^{\circ} \mathrm{C}$ for $5 \mathrm{~min}$, followed by 40 cycles of $95^{\circ} \mathrm{C}$ for $5 \mathrm{sec}$ and $60^{\circ} \mathrm{C}$ for $30 \mathrm{sec}$ (annealing). All primer sequences are presented in Table I.

Western blot analysis. ERK, p-ERK, CaMK II $\alpha$ and $\gamma$, OCN, COLL I, Runx2, pRb (S780) and the cell cycle marker p21 $1^{\text {Cip/Kip }}$ in MC3T3 cells were analyzed by western blotting. For inhibition of ERK and CaMK II by U0126 and KN93, $10 \mu \mathrm{M}$ KN93 or U0126 were added into a-MEM with $10 \%$ FBS for $12 \mathrm{~h}$ following FSS stimulation. Following treatment, cells were washed by PBS $\left(4^{\circ} \mathrm{C}\right) 3$ times, then lysed by $200 \mu \mathrm{l}$ RIPA (Beyotime Biotechnology Research Institute, P0013B) for 5 mins on ice. The cells were centrifuged $(16,200 \mathrm{x} g$ for $25 \mathrm{~min}$ at $4^{\circ} \mathrm{C}$ ) and the supernatant was used for analysis. The concentration of the protein was determined by a BCA kit (NCI3227CH; Thermo Fisher Scientific, Inc.). Equal amounts of total cellular protein (30 $\mu \mathrm{g}$ per lane) were separated via
$10 \%$ of the SDS-PAGE gel, and then electrotransferred to polyvinylidene difluoride membranes (Immobilon-P; EMD Millipore, Billerica, MA, USA) at $340 \mathrm{~mA}$ for $65 \mathrm{mins}$. Blots were incubated with a 1:1,000 dilution of each primary antibody overnight at $4^{\circ} \mathrm{C}$. Primary antibody binding was detected using a secondary antibody conjugated to horseradish peroxidase with a 1:5,000 dilution for $1 \mathrm{~h}$ at room temperature, and enhanced using an enhanced chemiluminescence assay kit (Amersham; GE Healthcare Life Sciences), according to the manufacturer's protocol. Chemiluminescence was imaged on a FUJIFILM LAS-3000 system (Fujifilm Holdings Corporation, Tokyo, Japan). Image Reader LAS 3000 (Fujifilm Holdings Corporation, Tokyo, Japan) was used for densitometric analysis. The basal levels of proteins were normalized to the level of $\beta$-actin protein.

Statistical analysis. All data are expressed as the mean \pm standard deviation. Statistical analyses were performed using SPSS version 13.0 (SPSS Inc., Chicago, IL, USA). A one-way analysis of variance with Duncan's multiple range test was used to examine the differences between groups. $\mathrm{P}<0.05$ was considered to indicate a statistically significant difference.

\section{Results}

Fluid shear stress in the G0/G1 phase promotes osteoblast differentiation. In order to determine the response of osteoblasts induced by FSS, MC3T3-E1 cells in the G0/G1 phase were subjected to $12 \mathrm{dyne} / \mathrm{cm}^{2} \mathrm{FSS}$ for $1 \mathrm{~h}$, and subsequently cultured in $\alpha$-MEM containing 10\% FBS for a further $24 \mathrm{~h}$. Cell differentiation was determined by analysis of ALP activity and by ALP staining. Compared with the control, FSS significantly increased ALP activity by $28 \%$ (Fig. 1A and B).

Runx2, which promotes the transcription of differentiated genes, is an important indicator of cell differentiation induced by FSS (27). OCN and COLL I, which are transcriptionally-regulated by Runx2, are two early markers of osteoblast differentiation. The results of the present study demonstrated that OCN, COLL I and Runx 2 mRNA expression was elevated by $5.59,4.05$ and 7.16 -fold, respectively (Fig. 1C). In addition, OCN, COLL I and Runx2 protein levels were upregulated by FSS (Fig. 1D).

The results of the present study indicated that FSS promoted osteoblast differentiation in the G0/G1 phase.

FSS arrests the cell cycle at the G0/G1 phase. Following exposure to FSS, the DNA content of cells was decreased by $11.9 \%$ 
A

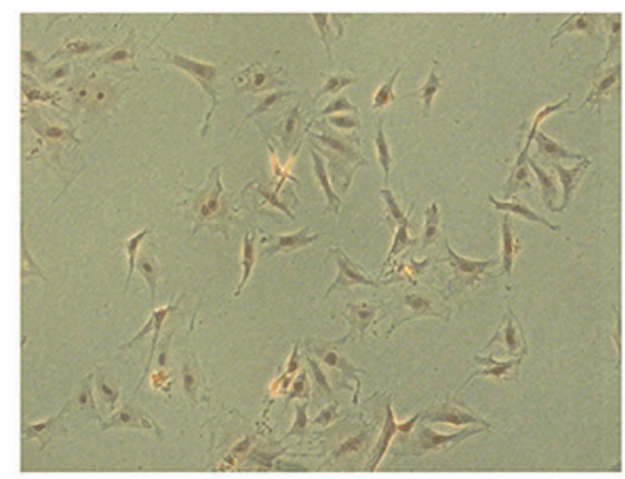

Con

B

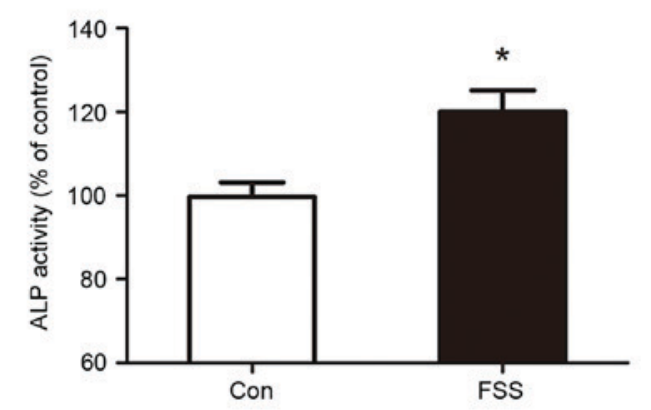

Alkaline phosphatase positive cells

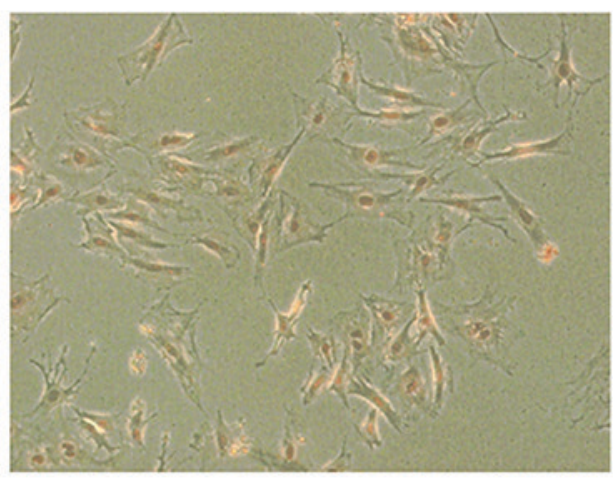

FSS

C

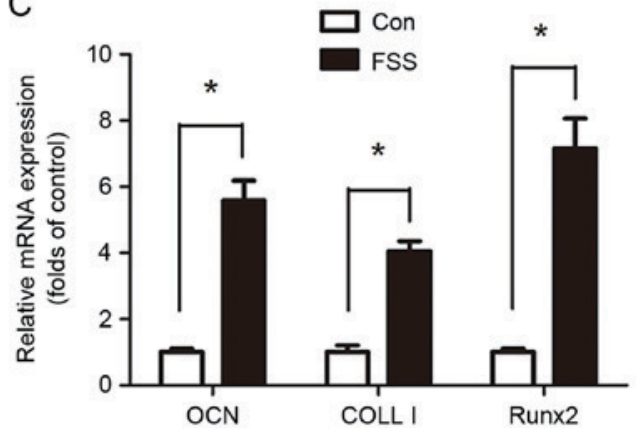

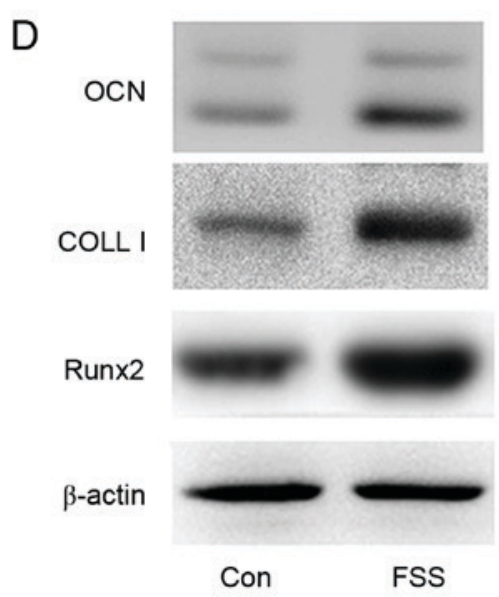

Figure 1. Effects of FSS on differentiation in MC3T3 cells. (A) ALP was stained using a staining kit. (B) ALP activity was assessed by the conversion of p-nitrophenyl phosphate to p-nitrophenol. (C) mRNA expression of COLL I, OCN and Runx2 were determined by reverse transcription-quantitative polymerase chain reaction analysis and compared with $\beta$-actin. (D) COLL I, OCN and Runx 2 activity was determined by western blotting and compared with $\beta$-actin. There was no obvious detachment of MC3T3 cells subjected to 12 dyne $/ \mathrm{cm}^{2}$ for $1 \mathrm{~h}$. The data are presented as the mean \pm standard deviation from at least three independent experiments. "P<0.05 vs. Con. FSS, fluid shear stress; ALP, alkaline phosphatase; COLL I, collagen type I; OCN, osteocalcin; Runx2, runt-related transcription factor 2 ; Con, control.

compared with the control (Fig. 2A). The percentage of cells in the $\mathrm{S}$ phase decreased to $6.46 \%$ compared with the control value of $16.34 \%$ (Fig. 2B and C). The results indicated that FSS inhibited proliferation through inhibition of the transition between the G0/G1 and S phases.

Promotion of osteoblast differentiation induced by FSS in the G0/G1 phase is associated with CaMK II and the ERK1/2 signaling pathway. CaMK II and ERK1/2 have been reported to regulate osteoblast differentiation induced by FSS (28). The present study further investigated the potential involvement of ERK1/2 and CaMK II during FSS-induced differentiation in the G0/G1 phase (Fig. 3). Western blotting demonstrated that both ERK1/2 and p-ERK1/2 in MC3T3-E1 cells increased following stimulation with FSS (Fig. 3A). Among the four isoforms of CaMKII, only CaMK II- $\alpha$ and $-\gamma$ have been observed to be expressed in osteoblasts, and CaMK II- $\alpha$ is involved in differentiation (20). The results of the present study demonstrated that the expression of CaMK II- $\alpha$ was increased following stimulation with FSS, while CaMK II- $\gamma$ was not significantly different between the control and FSS groups (Fig. 3A). In addition, FSS increased 
A

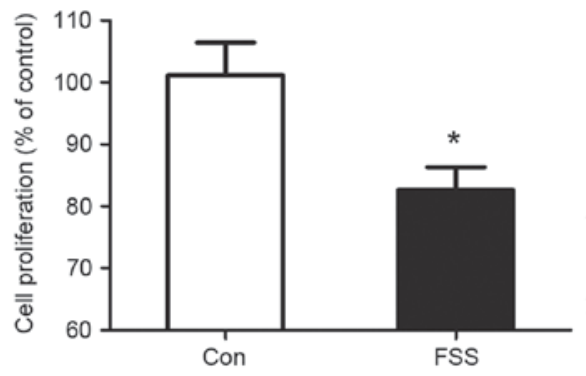

B

Percentage of different phases cells
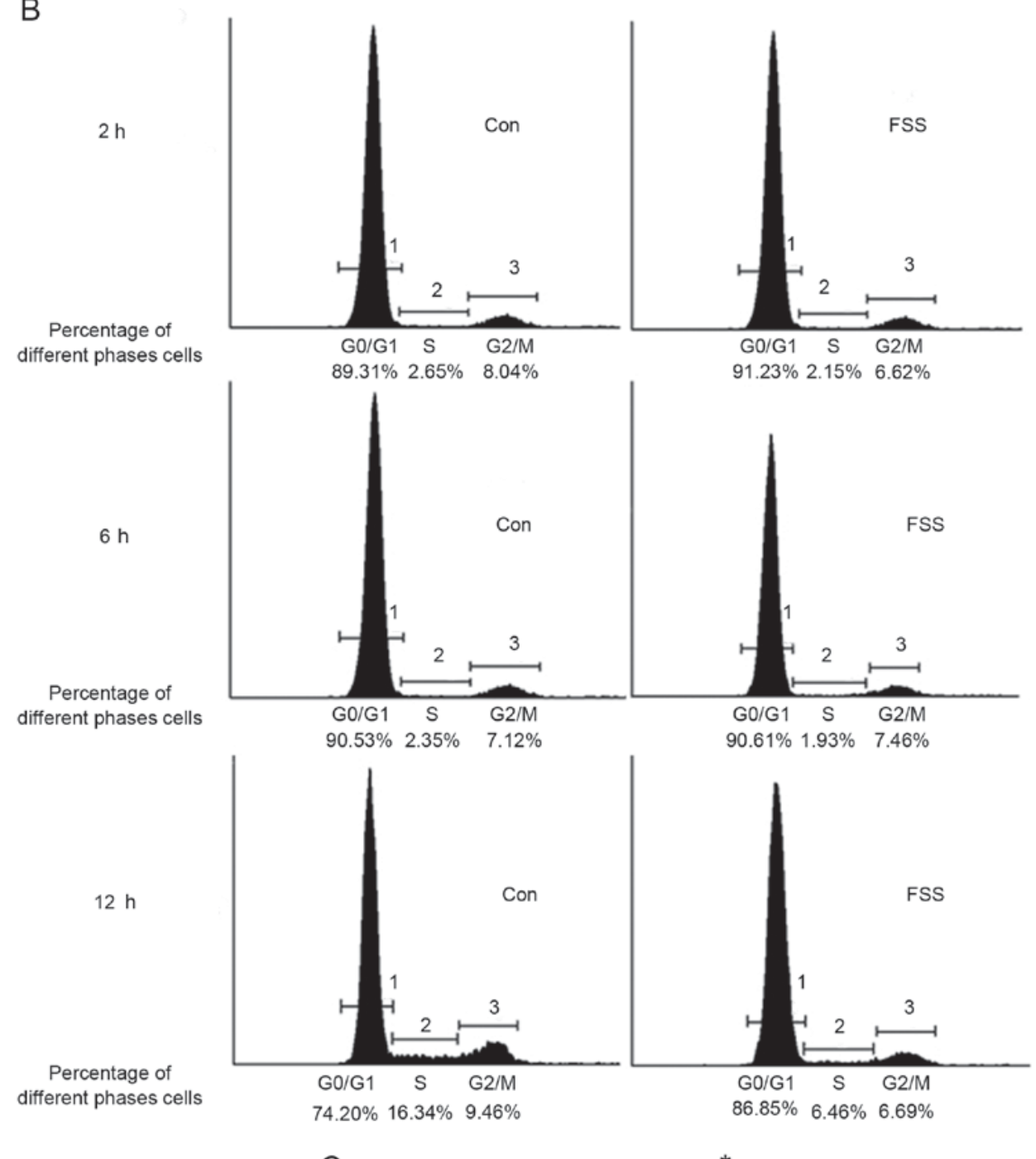

C

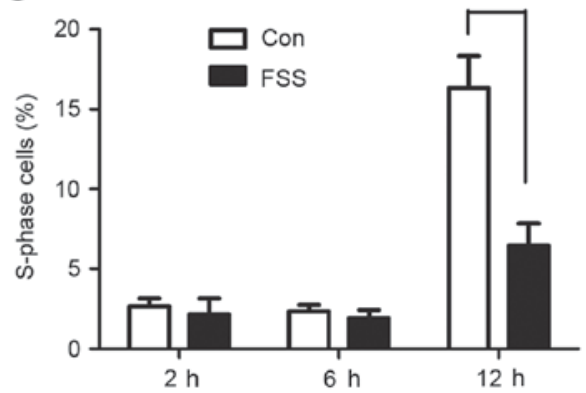

Figure 2. Effects of FSS on the proliferation of MC3T3 cells. (A) Cell proliferation was determined by bromodeoxyuridine assay. (B) Effect of shear stress on the cell cycle, including $(\mathrm{C})$ the number of cells in the $\mathrm{S}$ phase. DNA was stained with propidium iodide, and florescence was evaluated by flow cytometry. The data are the percentages of cells in each phase, as determined by CytExpert version 1.2.11.0 (Beckman Coulter, Inc.). The data are presented as the mean \pm standard deviation from at least three independent experiments. ${ }^{*} \mathrm{P}<0.05$ vs. Con. FSS, fluid shear stress; Con, control. 
A

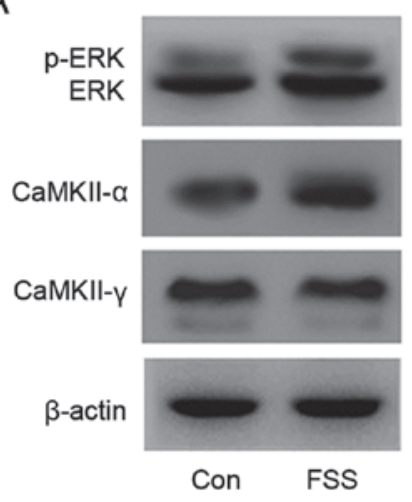

C

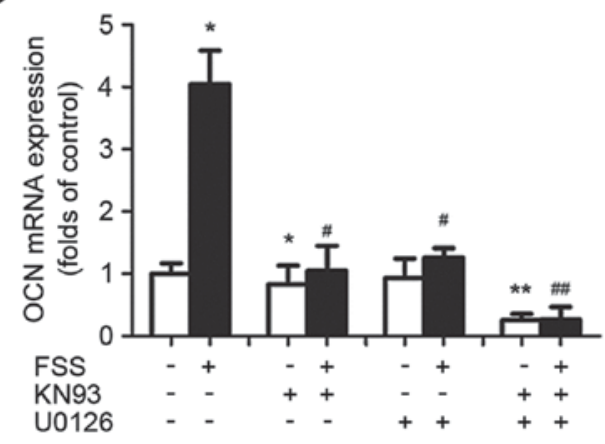

E

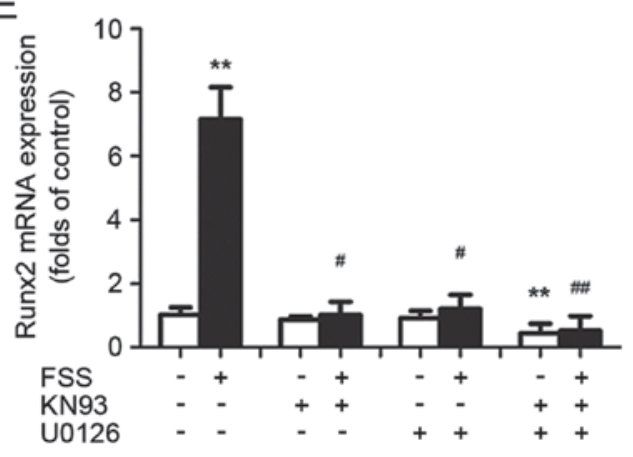

B

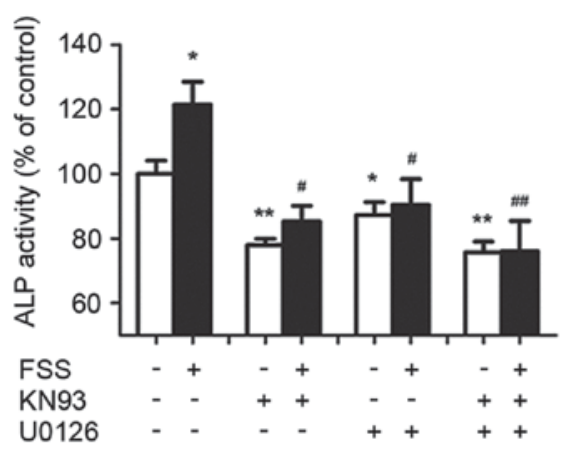

D

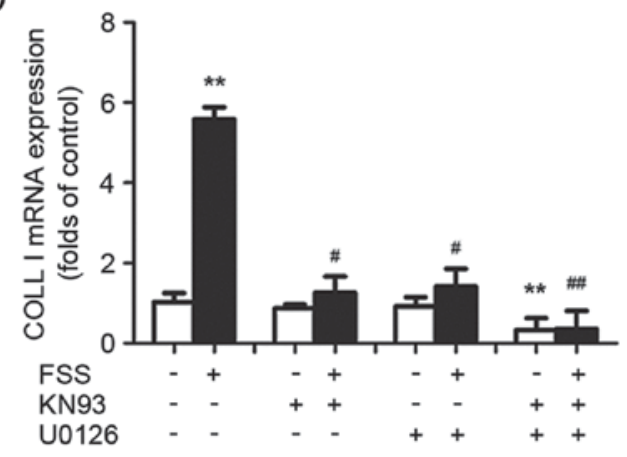

F

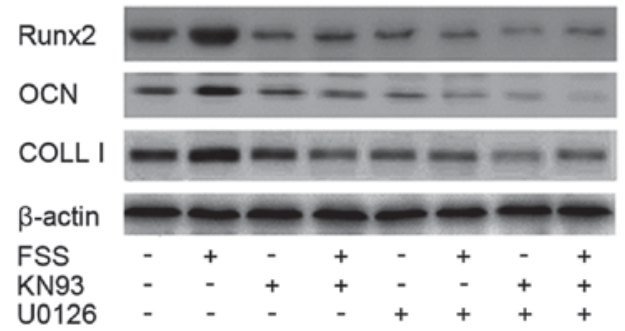

Figure 3. ERK and CaMK II pathways regulate FSS-induced osteoblast differentiation. (A) p-ERK, ERK, CaMK II $\alpha$ and CaMK II $\gamma$ levels were determined by western blotting and compared with $\beta$-actin. (B) Alkaline phosphatase activity was assessed by the conversion of p-nitrophenyl phosphate to p-nitrophenol. The mRNA expression of (C) OCN, (D) COLL I and (E) Runx 2 was determined using reverse transcription-quantitative polymerase chain reaction analysis and compared with $\beta$-actin. (F) COLL I, OCN and Runx 2 activity was determined by western blot analysis and compared with $\beta$-actin. The data are presented as the mean \pm standard deviation from at least three independent experiments. ${ }^{*} \mathrm{P}<0.05,{ }^{* *} \mathrm{P}<0.01$ vs. control group, ${ }^{\#} \mathrm{P}<0.05,{ }^{\#} \mathrm{P}<0.01$ vs. FSS group. ERK, extracellular signal-regulated kinase; p, phosphorylated; CaMK II, calcium/calmodulin-dependent protein kinase type II; OCN, osteocalcin; COLL I, collagen type I; Runx2, runt-related transcription factor 2; FSS, fluid shear stress; Con, control.

Runx2 activity, and the induction of Runx 2 was accompanied by an increase in ALP activity and the expression of OCN and COLL I (Fig. 1).

To ascertain whether the CaMK II or ERK1/2 pathways mediated osteoblast differentiation in response to FSS, KN93, an inhibitor of CaMK II, and U0126, an inhibitor of ERK1/2, were used to treat the cells. The results of the present study demonstrated that the induction of Runx 2 by FSS was partially inhibited when CaMK II or ERK1/2 was inhibited (Fig. 3E and F). It was additionally observed that treatment with KN93 and U0126 in the presence of FSS abolished ALP activity, and the transcription and expression of OCN and COLL I (Fig. 3B-D and F). The present results indicated that the CaMK II and ERK1/2 signaling pathways were necessary for osteoblast differentiation induced by FSS.

ERK1/2, not CaMK II, mediates FSS-induced p21 Cip/Kip upregulation and $p R b$ dephosphorylation. Induction of the cell cycle regulator $\mathrm{p} 21^{\mathrm{Cip} / \mathrm{Ki}}$ is an important indicator of ERK1/2-induced inhibition of proliferation (29-32). In the present study, FSS increased p21 ${ }^{\text {Cip/Kip }}$ (Fig. 4A), ERK1/2 and p-ERK1/2 activity (Fig. 3A). The induction of $\mathrm{p} 21^{\mathrm{Cip} / \mathrm{Kip}}$ was accompanied by $\mathrm{pRb}$ dephosphorylation and an $11.82 \%$ decrease in the number of proliferating cells (Fig. 4B).

To ascertain whether ERK1/2 mediated p21 Cip/Kip induction and MC3T3 cell proliferation in response to FSS, the effect 
A

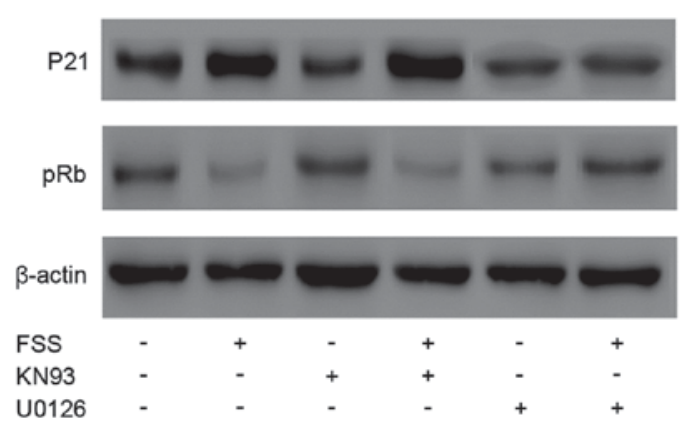

B

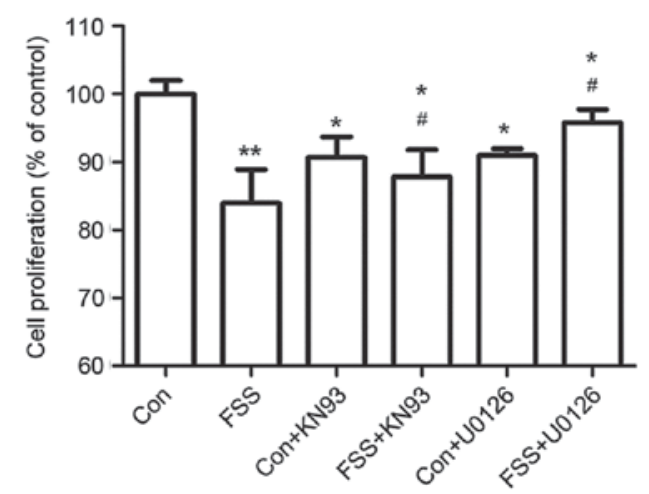

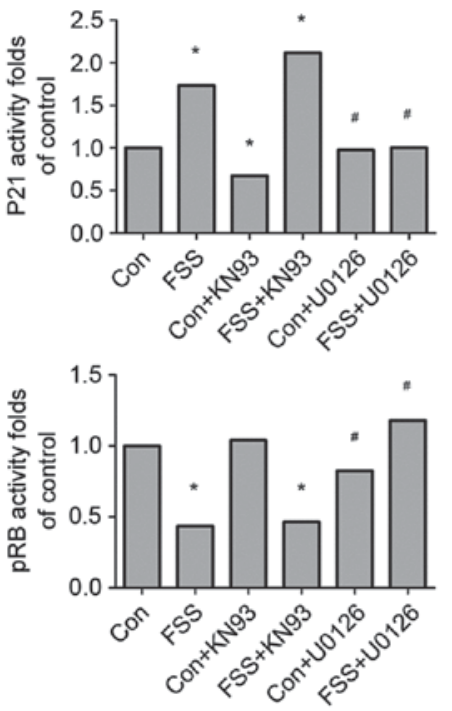

C

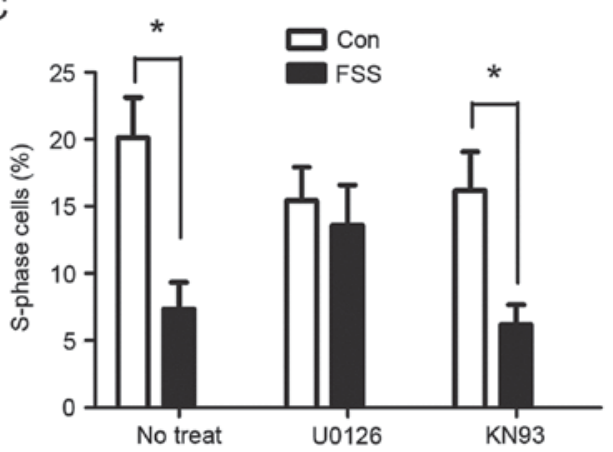

$\mathrm{D}$
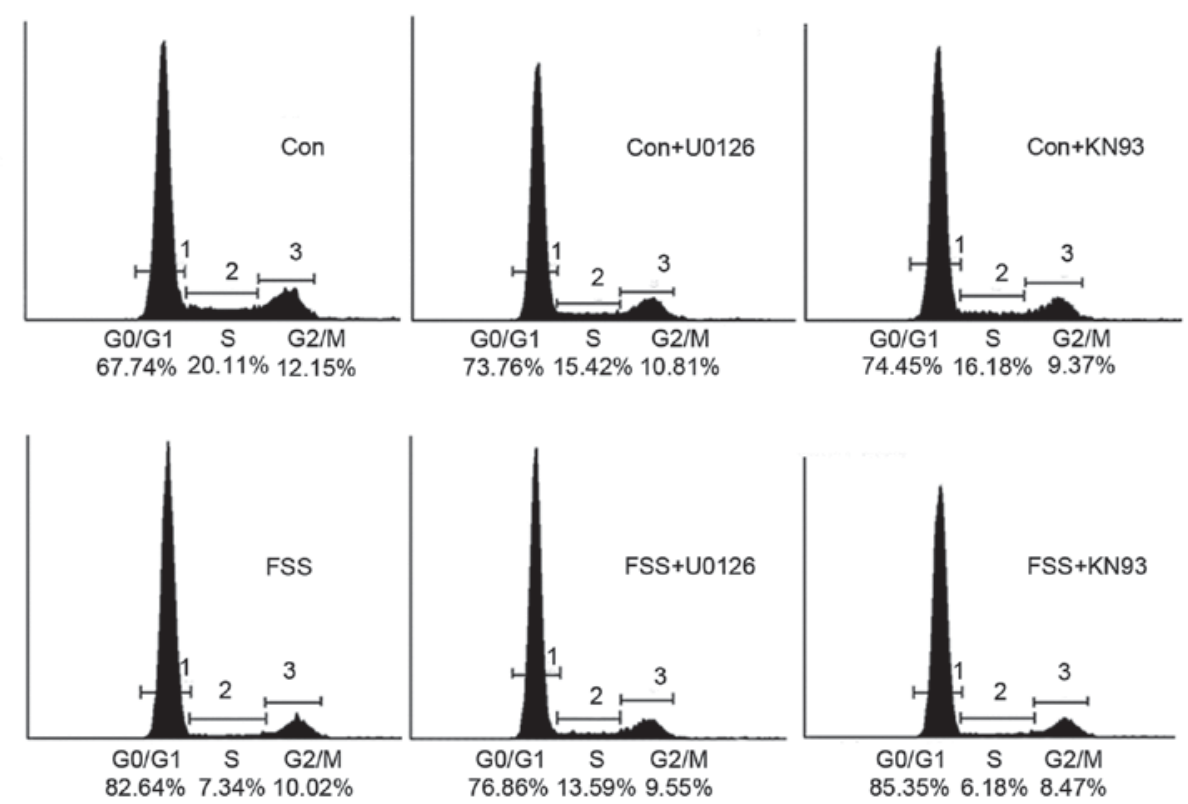

Figure 4. Extracellular signal-regulated kinase and calcium/calmodulin-dependent protein kinase type II pathways regulate FSS-induced osteoblast proliferation. (A) $\mathrm{p} 21^{\mathrm{Cip} / \mathrm{Kip}}$ and $\mathrm{pRb}$ levels were determined by western blot analysis and compared with $\beta$-actin. (B) Cell proliferation was determined by bromodeoxyuridine assay. (C) The number of cells in the S phase and (D) the effect of shear stress on the cell cycle. DNA was stained with propidium iodide, and florescence was evaluated by flow cytometry. The data are the percentages of cells in each phase determined by the EPICS profile analyzer. The data are presented as the mean \pm standard deviation from at least three independent experiments. ${ }^{*} \mathrm{P}<0.05,{ }^{* *} \mathrm{P}<0.01$ vs. control group, ${ }^{\#} \mathrm{P}<0.05,{ }^{\# \#} \mathrm{P}<0.01$ vs. FSS group. pRB, phosphorylated retinoblastoma-associated protein; FSS, fluid shear stress; Con, control.

of inhibiting ERK1/2 on osteoblasts stimulated with FSS was investigated. It was observed that the induction of $\mathrm{p} 21^{\mathrm{Ci} / \mathrm{Kip}}$ by FSS was partly decreased when ERK1/2 was inhibited. It was additionally demonstrated that treatment with U0126 in 
the presence of FSS increased cell numbers (Fig. 4B) and S phase re-entry (Fig. 4C and D), compared with the FSS group. The present results indicated that FSS inhibited MC3T3 cell proliferation, in part through the ERK1/2-p21 $1^{\mathrm{Cip} / \mathrm{Kip}}$ signaling pathway.

Although CaMK II mediated the differentiation of MC3T3 cells exposed to FSS, the induction of $\mathrm{p} 21^{\text {Cip/Kip }}$ by FSS was not decreased when cells were pretreated with KN93. Additionally, the inhibition of CaMK II during FSS stimulation did not increase cell numbers (Fig. 4B) compared with the FSS group. The results indicated that CaMK II was not implicated in the proliferation inhibited by FSS.

\section{Discussion}

Previous studies reported that FSS promoted the proliferation and differentiation of osteoblasts. However, the conditions of osteoblast proliferation and differentiation induced by FSS have rarely been reported. Proliferation and differentiation are exclusive cellular events. Cells enter into the cell cycle to commence proliferation, whereas cells exit the cell cycle prior to differentiation. Therefore, the present study investigated the effects of FSS on osteoblast-like MC3T3 cells in the G0/G1 phase, the period during which cell proliferation or differentiation is determined. It was observed that FSS in the G0/G1 phase promoted the differentiation of MC3T3 cells through the ERK1/2 and CaMK II signaling pathways, and partly arrested the cell cycle at the G0/G1 phase via the ERK1/2 pathway. The results of the present study provided evidence for the fact that proliferation and differentiation may not be promoted by FSS simultaneously, and demonstrated the necessity of further research to elucidate the mechanobiology of the effect of FSS on osteoblasts.

Loading of bone causes movement of interstitial fluid within bone. Bone exhibits the unique ability to modify its structure via bone-associated cells in response to fluid flow. Previous studies have focused on how the cells, including osteoblasts, respond to FSS (3-5). Although certain studies noted that FSS promoted osteoblast proliferation or differentiation $(33,34)$, further details of the process were not reported. Proliferation and differentiation are distinct cellular events that occur at different cell stages. Therefore, further studies using different cell populations induced by FSS are required. In the present study, in order to demonstrate when FSS altered the differentiation or proliferation of osteoblasts, osteoblasts at the G0/G1 phase, the period during which cell differentiation or entry into the cell cycle is determined, were obtained and the roles of FSS were investigated. The results of the present study demonstrated that FSS decreased the cell numbers, although it increased the expression of Runx2, COLL I and OCN, which are markers of osteoblast differentiation. The results of the present study demonstrated that FSS during the G0/G1 phase induced the differentiation of osteoblasts while arresting the cell cycle at the G0/G1 phase.

It has been reported that osteoblasts express Runx 2 in the G0/G1 phase. Runx2 is important for the differentiation of osteoblasts (35-38), and is able to directly stimulate the transcription of osteoblast-associated genes, including ALP, COLL I and OCN, by binding to specific enhancer regions $(19,39,40)$. The results of the present study demonstrated that FSS induced an increase in Runx 2 expression, which indicated that FSS promoted Runx 2 activity in MC3T3 cells. It was hypothesized that Runx2 may be an important factor enabling FSS to promote the differentiation of osteoblasts in the G0/G1 phase. The results of the present study demonstrated that the increase in Runx 2 activity was accompanied by activation of CaMK II $\alpha$ and ERK1/2. Additionally, the inhibition of CaMK II or ERK1/2 decreased the protein level of Runx2, and reduced ALP activity and the expression of OCN and COLL I. The combination of KN93 and U0126 inhibited the expression of FSS-induced differentiation markers. Previous studies have reported that CaMK II and ERK1/2 may be involved in regulating proliferation and differentiation $(29-31,41,42)$. Inhibition of ERK1/2 by U0126 and CaMK II by KN93 decreased FSS-induced Runx2 activity, indicating that Runx 2 was the downstream regulator of ERK $1 / 2$ and CaMK II in osteoblast differentiation induced by FSS in the G0/G1 phase. The results of the present study demonstrated that FSS in the G0/G1 phase promoted the differentiation of osteoblasts by enhancing the protein level of Runx2 via the CaMK II and ERK1/2 signaling pathways.

The notable markers of proliferative inhibition are $\mathrm{pRb}$ dephosphorylation and G0/G1 phase arrest. p21 $1^{\text {Cip/Kip }}$, which inhibits pRb phosphorylation (43-45), has been reported to inhibit proliferation in different cell types $(35,46,47)$. Runx2 interacts with $\mathrm{pRb}(9,10)$ and the overexpression of Runx2 suppresses proliferation and causes a delay in the G1 phase of MC3T3 preosteoblasts (27). It was considered that increased expression of Runx 2 induced by FSS may be associated with $\mathrm{pRb}$ regulation, which was necessary for $\mathrm{S}$ phase entry. Notably, the results of the present study demonstrated that the high expression of Runx 2 induced by FSS was accompanied by $\mathrm{pRb}$ dephosphorylation and an upregulation of $\mathrm{p} 21^{\text {Cip/Kip }}$. In addition, the present study investigated whether CaMK II and ERK1/2 were involved in cell cycle regulation. It was observed that inhibition of ERK1/2 by U0126 increased cell numbers and $\mathrm{S}$ phase re-entry. However, inhibition of ERK $1 / 2$ in static control only partially inhibited cell entry into $\mathrm{S}$ phase. The ERK1/2 pathway has been demonstrated to be involved in the positive and negative regulation of cell growth (29-31). The results of the present study demonstrated that ERK1/2 induced by FSS primarily exerted negative regulation of the cell cycle. An additional signaling pathway, CaMK II, was observed to be irrelevant to cell cycle induction by FSS. The CaMK II pathway has been reported to be a stimulus for cell proliferation $(34,42)$. The present findings indicated that inhibition of CaMK II reduced cells numbers in static control, in accordance with these previous studies. The results of the present study demonstrated that CaMK II was not involved in the FSS-induced inhibition of S phase entry. Another notable feature of MC3T3 cells in the G0/G1 phase is the increased expression of $\mathrm{p} 21^{\mathrm{Cip} / \mathrm{Kip}}$ activity (27). The present study investigated the role of the ERK1/2 and CaMK II signaling pathways in $\mathrm{p} 21^{\mathrm{Cip} / \mathrm{Kip}}$ regulation. It was observed that FSS promoted $\mathrm{p} 21^{\mathrm{Cip} / \mathrm{Kip}}$ activity in MC3T3 cells. Inhibition of ERK1/2 by U0126 suppressed p21 $1^{\text {Cip/Kip }}$ activity induced by FSS, although inhibition of CaMK II had little effect on $\mathrm{p} 21^{\mathrm{Cip} / \mathrm{Kip}}$. Previous studies have reported that the inhibition of CaMK II induced p21 ${ }^{\text {Cip/Kip }}$ activity, which was mediated by cell proliferation in other cell types $(45,48,49)$. 
However, the results of the present study demonstrated that CaMK II was not involved in $\mathrm{p} 21^{\text {Cip/Kip }}$ expression induced by FSS in MC3T3 cells.

In conclusion, in the present study, we found that in the G0/G1 phase, FSS promoted osteoblast differentiation via the CaMK II and ERK1/2 signaling pathways although it inhibited proliferation via the ERK1/2-p21 pathway only. The present findings provided a deeper understanding of the mechanism underlying osteoblastic mechanobiology.

\section{Acknowledgements}

The present study was supported by National Natural Scientific Foundation of China (grant nos. 11372244 and 31170893).

\section{References}

1. Knothe Tate ML, Knothe U and Niederer P: Experimental elucidation of mechanical load-induced fluid flow and its potential role in bone metabolism and functional adaptation. Am J Med Sci 316: 189-195, 1998.

2. Kufahl RH and Saha S: A theoretical model for stress-generated fluid flow in the canaliculi-lacunae network in bone tissue. J Biomech 23: 171-180, 1990.

3. Kapur S, Baylink DJ and Lau KH: Fluid flow shear stress stimulates human osteoblast proliferation and differentiation through multiple interacting and competing signal transduction pathways. Bone 32: 241-251, 2003.

4. Liu X, Zhang X and Lee I: A quantitative study on morphological responses of osteoblastic cells to fluid shear stress. Acta Biochim Biophys Sin (Shanghai) 42: 195-201, 2010.

5. Yu W, Qu H, Hu G, Zhang Q, Song K, Guan H, Liu T and Qin J: A microfluidic-based multi-shear device for investigating the effects of low fluid-induced stresses on osteoblasts. PLoS One 9 e89966, 2014.

6. Prescott DM: Regulation of cell reproduction. Cancer Res 28: 1815-1820, 1968

7. Dyson N: The regulation of E2F by pRB-family proteins. Genes Dev 12: 2245-2262, 1998.

8. Spencer SL, Cappell SD, Tsai FC, Overton KW, Wang CL and Meyer T: The proliferation-quiescence decision is controlled by a bifurcation in CDK2 activity at mitotic exit. Cell 155: 369-383, 2013.

9. Luan Y, Yu XP, Xu K, Ding B, Yu J, Huang Y, Yang N, Lengyel P, Di Cesare PE and Liu CJ: The retinoblastoma protein is an essential mediator of osteogenesis that links the p204 protein to the Cbfal transcription factor thereby increasing its activity. J Biol Chem 282: 16860-16870, 2007.

10. Thomas DM, Carty SA, Piscopo DM, Lee JS, Wang WF, Forrester WC and Hinds PW: The retinoblastoma protein acts as a transcriptional coactivator required for osteogenic differentiation. Mol Cell 8: 303-316, 2001.

11. Akhter MP, Wells DJ, Short SJ, Cullen DM, Johnson ML, Haynatzki GR, Babij P, Allen KM, Yaworsky PJ, Bex F and Recker RR: Bone biomechanical properties in LRP5 mutant mice. Bone 35: 162-169, 2004.

12. Chen NX, Geist DJ, Genetos DC, Pavalko FM and Duncan RL: Fluid shear-induced NFkappaB translocation in osteoblasts is mediated by intracellular calcium release. Bone 33: 399-410, 2003.

13. Chen NX, Ryder KD, Pavalko FM, Turner CH, Burr DB, Qiu J and Duncan RL: $\mathrm{Ca}(2+)$ regulates fluid shear-induced cytoskeletal reorganization and gene expression in osteoblasts. Am J Physiol Cell Physiol 278: C989-C997, 2000.

14. Jing D, Baik AD, Lu XL, Zhou B, Lai X, Wang L, Luo E and Guo XE: In situ intracellular calcium oscillations in osteocytes in intact mouse long bones under dynamic mechanical loading. FASEB J 28: 1582-1592, 2014.

15. Lu XL, Huo B, Park M and Guo XE: Calcium response in osteocytic networks under steady and oscillatory fluid flow. Bone 51: 466-473, 2012

16. Pilbeam CC, Raisz LG, Voznesensky O, Alander CB, Delman BN and Kawaguchi $\mathrm{H}$ : Autoregulation of inducible prostaglandin $\mathrm{G} / \mathrm{H}$ synthase in osteoblastic cells by prostaglandins. J Bone Miner Res 10: 406-414, 1995.
17. Wadhwa S, Choudhary S, Voznesensky M, Epstein M, Raisz L and Pilbeam C: Fluid flow induces COX-2 expression in MC3T3-E1 osteoblasts via a PKA signaling pathway. Biochem Biophys Res Commun 297: 46-51, 2002.

18. Wang B, Du T, Wang Y, Yang C, Zhang S and Cao X: Focal adhesion kinase signaling pathway is involved in mechanotransduction in MG-63 cells. Biochem Biophys Res Commun 410: 671-676, 2011.

19. Ducy P, Zhang R, Geoffroy V, Ridall AL and Karsenty G: Osf2/Cbfa1: A transcriptional activator of osteoblast differentiation. Cell 89: 747-754, 1997.

20. Zayzafoon M, Fulzele K and McDonald JM: Calmodulin and calmodulin-dependent kinase IIalpha regulate osteoblast differentiation by controlling c-fos expression. J Biol Chem 280: 7049-7059, 2005.

21. Gebken J, Lüders B, Notbohm H, Klein HH, Brinckmann J, Müller PK and Bätge B: Hypergravity stimulates collagen synthesis in human osteoblast-like cells: Evidence for the involvement of p44/42 MAP-kinases (ERK 1/2). J Biochem 126: 676-682, 1999.

22. Jessop HL, Rawlinson SC, Pitsillides AA and Lanyon LE: Mechanical strain and fluid movement both activate extracellular regulated kinase (ERK) in osteoblast-like cells but via different signaling pathways. Bone 31: 186-194, 2002.

23. Matsuda N, Morita N, Matsuda K and Watanabe M: Proliferation and differentiation of human osteoblastic cells associated with differential activation of MAP kinases in response to epidermal growth factor, hypoxia, and mechanical stress in vitro. Biochem Biophys Res Commun 249: 350-354, 1998.

24. Wadhwa S, Godwin SL, Peterson DR, Epstein MA, Raisz LG and Pilbeam CC: Fluid flow induction of cyclo-oxygenase 2 gene expression in osteoblasts is dependent on an extracellular signal-regulated kinase signaling pathway. J Bone Miner Res 17: 266-274, 2002.

25. You J, Reilly GC, Zhen X, Yellowley CE, Chen Q, Donahue HJ and Jacobs CR: Osteopontin gene regulation by oscillatory fluid flow via intracellular calcium mobilization and activation of mitogen-activated protein kinase in MC3T3-E1 osteoblasts. J Biol Chem 276: 13365-13371, 2001.

26. Livak KJ and Schmittgen TD: Analysis of relative gene expression data using real-time quantitative PCR and the 2(-Delta Delta C(T)) method. Methods 25: 402-408, 2001.

27. Galindo M, Pratap J, Young DW, Hovhannisyan H, Im HJ, Choi JY, Lian JB, Stein JL, Stein GS and van Wijnen AJ: The bone-specific expression of Runx 2 oscillates during the cell cycle to support a G1-related antiproliferative function in osteoblasts. J Biol Chem 280: 20274-20285, 2005.

28. Franceschi RT, Xiao G, Jiang D, Gopalakrishnan R, Yang S and Reith E: Multiple signaling pathways converge on the Cbfa1/Runx 2 transcription factor to regulate osteoblast differentiation. Connective Tissue Res 44 (Suppl 1): S109-S116, 2003.

29. Enarsson M, Erlandsson A, Larsson H and Forsberg-Nilsson K: Extracellular signal-regulated protein kinase signaling is uncoupled from initial differentiation of central nervous system stem cells to neurons. Mol Cancer Res 1: 147-154, 2002.

30. Howe AK and Juliano RL: Distinct mechanisms mediate the initial and sustained phases of integrin-mediated activation of the Raf/MEK/mitogen-activated protein kinase cascade. J Biol Chem 273: 27268-27274, 1998.

31. Park KS, Lee NG, Lee KH, Seo JT and Choi KY: The ERK pathway involves positive and negative regulations of HT-29 colorectal cancer cell growth by extracellular zinc. Am J Physiol Gastrointest Liver Physiol 285: G1181-G1188, 2003.

32. Woods D, Parry D, Cherwinski H, Bosch E, Lees E and McMahon M: Raf-induced proliferation or cell cycle arrest is determined by the level of Raf activity with arrest mediated by p21Cip1. Mol Cell Biol 17: 5598-5611, 1997.

33. Vezeridis PS, Semeins CM, Chen Q and Klein-Nulend J: Osteocytes subjected to pulsating fluid flow regulate osteoblast proliferation and differentiation. Biochem Biophys Res Commun 348: 1082-1088, 2006.

34. Li YJ, Batra NN, You L, Meier SC, Coe IA, Yellowley CE and Jacobs CR: Oscillatory fluid flow affects human marrow stromal cell proliferation and differentiation. J Orthop Res 22: 1283-1289, 2004.

35. Chau JF, Leong WF and Li B: Signaling pathways governing osteoblast proliferation, differentiation and function. Histol Histopathol 24: 1593-1606, 2009. 
36. Komori T: Cbfa1/Runx2, an essential transcription factor for the regulation of osteoblast differentiation. Nihon Rinsho 60 (Suppl 3): S91-S97, 2002 (In Japanese).

37. Komori $\mathrm{T}$ : Regulation of osteoblast differentiation by Run $\times 2$. Adv Exp Med Biol 658: 43-49, 2010.

38. Zhao LG, Chen SL, Teng YJ, An LP, Wang J, Ma JL and Xia YY: The MEK5/ERK5 pathway mediates fluid shear stress promoted osteoblast differentiation. Connect Tissue Res 55: 96-102, 2014.

39. Kern B, Shen J, Starbuck M and Karsenty G: Cbfa1 contributes to the osteoblast-specific expression of type I collagen genes. J Biol Chem 276: 7101-7107, 2001.

40. Selvamurugan N, Chou WY, Pearman AT, Pulumati MR and Partridge NC: Parathyroid hormone regulates the rat collagenase- 3 promoter in osteoblastic cells through the cooperative interaction of the activator protein-1 site and the runt domain binding sequence. J Biol Chem 273: 10647-10657, 1998.

41. Braun AP and Schulman H: The multifunctional calcium/calmodulin-dependent protein kinase: From form to function. Annu Rev Physiol 57: 417-445, 1995.

42. Colomer JM and Means AR: Chronic elevation of calmodulin in the ventricles of transgenic mice increases the autonomous activity of calmodulin-dependent protein kinase II, which regulates atrial natriuretic factor gene expression. Mol Endocrinol 14: 1125-1136, 2000.

43. Akimoto S, Mitsumata M, Sasaguri T and Yoshida Y: Laminar shear stress inhibits vascular endothelial cell proliferation by inducing cyclin-dependent kinase inhibitor p21(Sdi1/Cip1/Waf1). Circ Res 86: 185-190, 2000.
44. Jung GA, Yoon JY, Moon BS, Yang DH, Kim HY, Lee SH, Bryja V, Arenas E and Choi KY: Valproic acid induces differentiation and inhibition of proliferation in neural progenitor cells via the beta-catenin-Ras-ERK-p21Cip/WAF1 pathway. BMC Cell Biol 9: 66, 2008.

45. Yuan K, Chung LW, Siegal GP and Zayzafoon M: Alpha-CaMKII controls the growth of human osteosarcoma by regulating cell cycle progression. Lab Invest 87: 938-950, 2007.

46. Plasilova M, Schonmeyr B, Fernandez J, Clavin N, Soares M and Mehrara BJ: Accelerating stem cell proliferation by down-regulation of cell cycle regulator p21. Plastic Reconstr Surg 123: 149S-157S, 2009.

47. James AW: Review of Signaling Pathways Governing MSC Osteogenic and Adipogenic Differentiation. Scientifica 2013: 684736, 2013

48. An P, Tian Y, Chen M and Luo $\mathrm{H}$ : $\mathrm{Ca}(2+) /$ calmodulin-dependent protein kinase II mediates transforming growth factor- $\beta$-induced hepatic stellate cells proliferation but not in collagen $\alpha 1(\mathrm{I})$ production. Hepatol Res 42: 806-818, 2012.

49. Choi J and Husain M: Calmodulin-mediated cell cycle regulation: New mechanisms for old observations. Cell Cycle 5: 2183-2186, 2006. 